\title{
Wild chimpanzees are infected with homologous types of human malaria
}

\author{
Marco Kaiser ${ }^{1,2^{*}}$, Dorothy H Bray ${ }^{3}$, Zinta Zommers ${ }^{4}$, Emmanuel Couacy-Hymann ${ }^{5}$, Thomas R Gillespie ${ }^{6,7}$, \\ Heinz Ellerbrok', Fabian H Leendertz ${ }^{8,9}$ \\ From Parasite to Prevention: Advances in the understanding of malaria \\ Edinburgh, UK. 20-22 October 2010
}

\section{Background}

Despite ongoing - and in some regions escalating morbidity and mortality associated with malaria parasites, evolutionary epidemiology of Plasmodium is not well characterized. Recent studies using molecular approaches demonstrated that wild and captive gorillas and captive bonobos and chimpanzees are infected with $P$. falciparum and that these apes harbor parasites broadly related to $P$. falciparum[1]. Captive chimpanzees and bonobos had malaria parasites related to human $P$. ovale and $P$. malariae and various monkeys and one semi-wild chimpanzee had $P$. vivax[2]. It is not clear whether these apes harbor naturally these parasites or whether they are transmitted from humans. Most of the examined animals had close contact with humans, comparable studies in wild living apes are missing. We provide the first survey of Plasmodium diversity in wild chimpanzees living in an undisturbed tropical rainforest in Africa.

\section{Methods}

We examined tissue from 16 wild West African chimpanzees that lived in the Tai National Park, Ivory Coast, where human contact with animals is limited to researchers who access the territory only during the day. Samples were collected from animals that died primarily from anthrax or respiratory disease. Generic real time PCR assay was used to detect all known Plasmodium species.

\section{Results}

$11 / 16(68 \%)$ animals tested positive. Sequence analyses of cytB and $18 \mathrm{~S}$ rRNA genes identified $P$. malariae,
P. ovale, $P$. vivax, $P$. gaboni, $P$. reichenowi, $P$. billcollinsi and P. billbraii.

\section{Discussion}

Previous examination of the role of our closest phylogenetic relatives, the great apes, in the evolution and persistence of human malarias has been limited by a lack of data from wild ape populations. Interpretation of patterns of malaria infection in captive ape populations must consider ample opportunities for human to ape transmission, negating the opportunity to investigate the evolutionary origins and public health-related risks of these parasites. Our examination of malaria parasites in wild chimpanzees demonstrates that these apes are most likely naturally infected with Plasmodium species homologous to $P$. malariae, $P$. vivax and $P$. ovale as well as $P$. falciparum. Whether wild great apes are the origin of these malaria types requires further investigation but they may act as reservoir of infection. These results have important implications for global efforts underway to eradicate malaria in humans including vaccine development based on animal variants of human parasites.

\footnotetext{
Author details

${ }^{1}$ Centre for Biological Safety-1; Robert Koch-Institute, D-13353 BerlinWedding, Germany. ${ }^{2}$ GenExpress GmbH, D-1 2103 Berlin, Germany. ${ }^{3}$ ImmunoClin Ltd, London N12 8PE, UK. ${ }^{4}$ Wildlife Conservation Research Unit, Recanati-Kaplan Centre, Department of Zoology, University of Oxford, Tubney OX13 5QL, UK. ' LANADA/ LCPA, BP 206, Bingerville, Ivory Coast. ${ }^{6}$ Department of Environmental Studies and Program in Population Biology, Ecology and Evolution, Emory University, Atlanta 30322, Georgia, USA. 'Department of Environmental and Occupational Health, Rollins School of Public Health, Emory University, Atlanta 30322, Georgia, USA. ${ }^{8}$ Research Group Emerging Zoonoses; Robert Koch-Institute, D-13353 Berlin-Wedding, Germany. ${ }^{9}$ Department of Primatology, Max-Planck-Institute for Evolutionary Anthropology, 04103 Leipzig, Germany.
} 


\section{References}

1. Prugnolle F, Durand P, Neel C, Ollomo B, Ayala FJ, Arnathau C, Etienne L, Mpoudi-Ngole E, Nkoghe D, Leroy E, Delaporte E, Peeters M, Renaud F: African great apes are natural hosts of multiple related malaria species, including Plasmodium falciparum. Proc Natl Acad Sci USA 2010, 107:1458-63.

2. Krief S, Escalante AA, Pacheco MA, Mugisha L, André C, Halbwax M, Fischer A, Krief JM, Kasenene JM, Crandfield M, Cornejo OE, Chavatte JM, Lin C, Letourneur F, Grüner AC, McCutchan TF, Rénia L, Snounou G: On the diversity of malaria parasites in African apes and the origin of Plasmodium falciparum from Bonobos. PLoS Pathog 2010, 6:e1000765.

doi:10.1186/1475-2875-9-S2-021

Cite this article as: Kaiser et al:: Wild chimpanzees are infected with homologous types of human malaria. Malaria Journal 2010 9(Suppl 2): O21.

\section{Submit your next manuscript to BioMed Central} and take full advantage of:

- Convenient online submission

- Thorough peer review

- No space constraints or color figure charges

- Immediate publication on acceptance

- Inclusion in PubMed, CAS, Scopus and Google Scholar

- Research which is freely available for redistribution

Submit your manuscript at www.biomedcentral.com/submit 